Деркач Тетяна, доктор економічних наук, доцент, Міжнародний гуманітарний університет, завідувачка кафедри менеджменту, м. Одеса, ORCID ID 0000-0003-1431-7300, e-mail: rubinodessa@gmail.com

\title{
РОЛЬ ХІМІЧНОЇ ПРОМИСЛОВОСТІ В ЕКОНОМІЦІ УКРАЇНИ
}

В статті представлено результати дослідження розвитку хімічної промисловості та пї роль в національному господарстві України. Визначена тенденція змінювання виручки від реалізації та питомої ваги хімічного виробництва в промисловості країни. Охарактеризований вплив хімічної галузі на ринок праці та рівень заробітної плати в галузі. Темпи зростання заробітної плати співставленні з індексом споживчих цін. Проаналізована частка витрат на охорону навколишнього середовища серед галузей переробної промисловості. 3 урахуванням того, що енергоресурси та їх вартість - одна 3 найгостріших проблем вітчизняної економіки, визначена динаміка використання теплової та електроенергії в хімічному виробництві. Розглянута структура капітальних інвестиції в галузях переробної промисловості Україні та динаміка капітальних витрат в хімічному виробництві. Представлений кореляційний та регресійний аналіз динаміки капітальних вкладень в галузь та динаміки обсягів реалізації. Проаналізовані основні показники, що характеризують інноваційну активність в хімічній промисловості.

Ключові слова: хімічна промисловість, хімічні речовини та хімічна продукція, ринок праці, екологічні витрати, капітальні інвестиції, обсяг виробництва, інноваційна активність галузі.

Деркач Татьяна, доктор экономических наук, доцент, Международный гуманитарный университет, заведующая кафедрой менеджмента,

г. Одесса

\section{РОЛЬ ХИМИЧЕСКОЙ ПРОМЫШЛЕННОСТИ В ЭКОНОМИКЕ УКРАИНЫ}

В статье представлены результаты исследования развития химической промышленности и ее роль в национальном хозяйстве Украины. Определена тенденция изменения выручки от реализации и удельного веса химического производства в промышленности страны. Охарактеризовано влияние химической отрасли на рынок труда и уровень заработной платы в отрасли. Темпы роста заработной платы сопоставлены с индексом потребительских цен. Проанализирована доля расходов на охрану окружающей среды среди отраслей перерабатывающей промышленности. С учетом того, что энергоресурсы и их стоимость - одна из самых острых проблем отечественной экономики, определена динамика использования тепловой и электроэнергии в химическом производстве. Рассмотрена структура капитальных инвестиций в отраслях перерабатывающей промышленности Украины и динамика капитальных затрат в химическом производстве. Представлен корреляционный и регрессионный анализ динамики капитальных вложений в отрасль и динамики объемов реализации. Проанализированы основные показатели, характеризующие инновационную активность в химической промышленности.

Ключевые слова: химическая промышленность, химические вещества и химическая продукция, рынок труда, экологические расходы, капитальные инвестиции, объем производства, инновационная активность отрасли.

Derkach Tatyana, Doctor of Economic Sciences, Associate Professor, International Humanitarian University, Head of the Department of Management, Odessa 


\section{THE ROLE OF THE CHEMICAL INDUSTRY IN THE ECONOMY OF UKRAINE}

Introduction. Today the chemical industry provides the expanding of the raw material base in many industries from construction to pharmaceutical and food industries. In developed countries the chemical industry is developing at an accelerated rate due to its high scientific intensity and innovative activity and under the influence of NTP.

The purpose of the article is to determine the peculiarities of production of chemicals and chemical products development and its role in the national economy of Ukraine.

Results. In 2018 the production of chemicals and chemical products ranked the seventh. In the period from 2010 till 2018 the chemical products sales tend to increase against this background of the sales volumes decreased in 2013 and 2016. In contrast to the absolute measurement the share of chemicals in total industrial production sales has a negative trend against the backdrop of minor upturns. In the chemical industry the number of personnel decreased annually reflecting the share of employees in the chemical industry among those employed in the industry. The reduction in the number of chemical enterprises has led to an increase in the number of unemployed, which in its turn has contributed to the increase in the number of migrant workers, mainly to the countries of Eastern and Western Europe as well as to the Russian Federation. Also, a significant drop in the production of basic chemicals is related to a significant increase in prices for raw materials, first of all, natural gas, as well as to the destruction of chemical enterprises and cooperative ties between enterprises in the course of hostilities in the East of the country. The negative changes in the industry have led to an increase in imports of chemicals and chemical products from the PRC, which contributes to job creation and income growth in the Chinese chemical industry, but worsens the situation in the national economy of Ukraine and the labor market in particular. It is proved that by the income criterion, chemical production is not among the top ten industries in this indicator, and, in combination with harmful and hazardous working conditions at chemical enterprises, is not particularly attractive to the workforce. Comparing the growth rate of wages in chemical production with the consumer price index shows the inflation rate exceeding the wage growth rate in 2014-2015 and in 2016. Wage growth rates have exceeded inflation in the consumer market. Of concern is the structure of environmental costs in the chemical industry: out of the total amount spent on environmental protection, $95.2 \%$ is current costs, while capital investments aimed at upgrading the logistics and technology improvements make up only $4.8 \%$, of which their cost of overhaul is $0.93 \%$. The reduction of electricity and heat consumption in chemical production was not due to the introduction of resource-saving technologies but rather due to a reduction in production and sales as a consequence of the economic crisis. The magnitude of the correlation coefficients between variable capital investment and sales volume changes numerically, but the negative direction of the relationship remains. This indicates either the inefficiency of the invested funds use or the fact that the volume of sales is influenced by negative factors of greater power which negate the positive impact of capital investments. The absolute and relative indices of innovatively active enterprises in the chemical industry tend to decrease being the negative factor for development,

Conclusions. One of the main results is that in order to provide a basis for the development of the chemical industry and to increase the efficiency of its activity, domestic chemical enterprises should give priority to the technical re-equipment of production and preparation of the production of innovative and competitive products. The basis for radical changes in the industries of the domestic industry is also the volume of capital investments. In order for a radical change in the environmental status of the industry to occur, the ratio of capital to operating costs should be prioritized in favor of capital investment. Development prospects are related to the improvement of the chemical enterprise resource structure; bringing the quality of products up to world standards, promoting the state (at the level of intergovernmental contacts) in entering new markets.

Key words: chemical industry, chemicals and chemical products, labor market, environmental costs, capital investment, production volume, industry innovation activity.

Постановка проблеми. Хімічна індустрія $є$ однією 3 найважливіших складових вітчизняної промисловості. Разом з металургією хімічна галузь є екологічно брудним виробництвом, проте, на відміну від інших галузей національної економіки, саме хімічна промисловість здатна знешкоджувати промислові та комунальні відходи, або розкладаючи їх на природні компоненти, або використовуючи їх як сировину для випуску побічної хімічної продукції.

В сучасному світі хімічна індустрія сприяє розширенню сировинної бази багатьох галузей матеріальної сфери: від будівництва до фармацевтичних та харчових виробництв. В розвинутих країнах під впливом НТП хімічна індустрія розвивається прискореними темпами завдяки високій наукомісткісті та інноваційній активності.

Розглянемо детальніше роль хімічної промисловості в національному господарстві України.

Аналіз останніх досліджень та публікацій. Питання оцінки сучасного стану, особливості 
функціонування та підходи до вирішення проблем розвитку хімічної індустрії розглядаються в працях провідних вітчизняних і зарубіжних вчених: Л. Й. Созанського, Л. П. Коваль, С. О. Іщук, К. Харт, П. Гутмана, Е. Фейга, В. Базилевича, В. Мандибури, Шевцова Г. З., М.В. Микитюка, О. І. Амоша,, Т. Василишина, В. Диканя, Л. Мельника, О. Мягкова, С. Смерічевського та ін..

Виділення не вирішених раніше частин загальної проблеми. Не дивлячись на велику кількість наукових праць, що стосуються особливостей, перешкод та тенденцій розвитку хімічної галузі в Україні, потребують подальшого дослідження питання, пов'язані з особливостями та перспективами розвитку хімічних підприємств в умовах провідної ролі хімічної промисловості в розвитку усіх галузей господарства.

Мета статті - визначення особливостей розвитку виробництва хімічних речовин і хімічної продукції та його роль в національній економіці України.

Виклад основного матеріалу. В Україні хімічна промисловість $є$ однією з основних галузей національної економіки. В 2018р. виробництво хімічних речовин і хімічної продукції зайняло сьоме місце (з часткою 2,6\% від обсягу реалізованої промислової продукції) серед галузей переробної промисловості після харчової промисловості (19,4\%), металургії (16,2\%), машинобудування $(6,9 \%)$, виробництва гуми та пластмас $(5,3 \%)$, виробництва коксу та продукції нафтоперероблення $(3,9 \%)$, виготовлення виробів 3 деревини та паперу $(3,4 \%)$.

Проаналізуємо динаміку обсягів реалізації та питомої ваги хімічної продукції в загальному обсязі промислової реалізації (рис. 1):

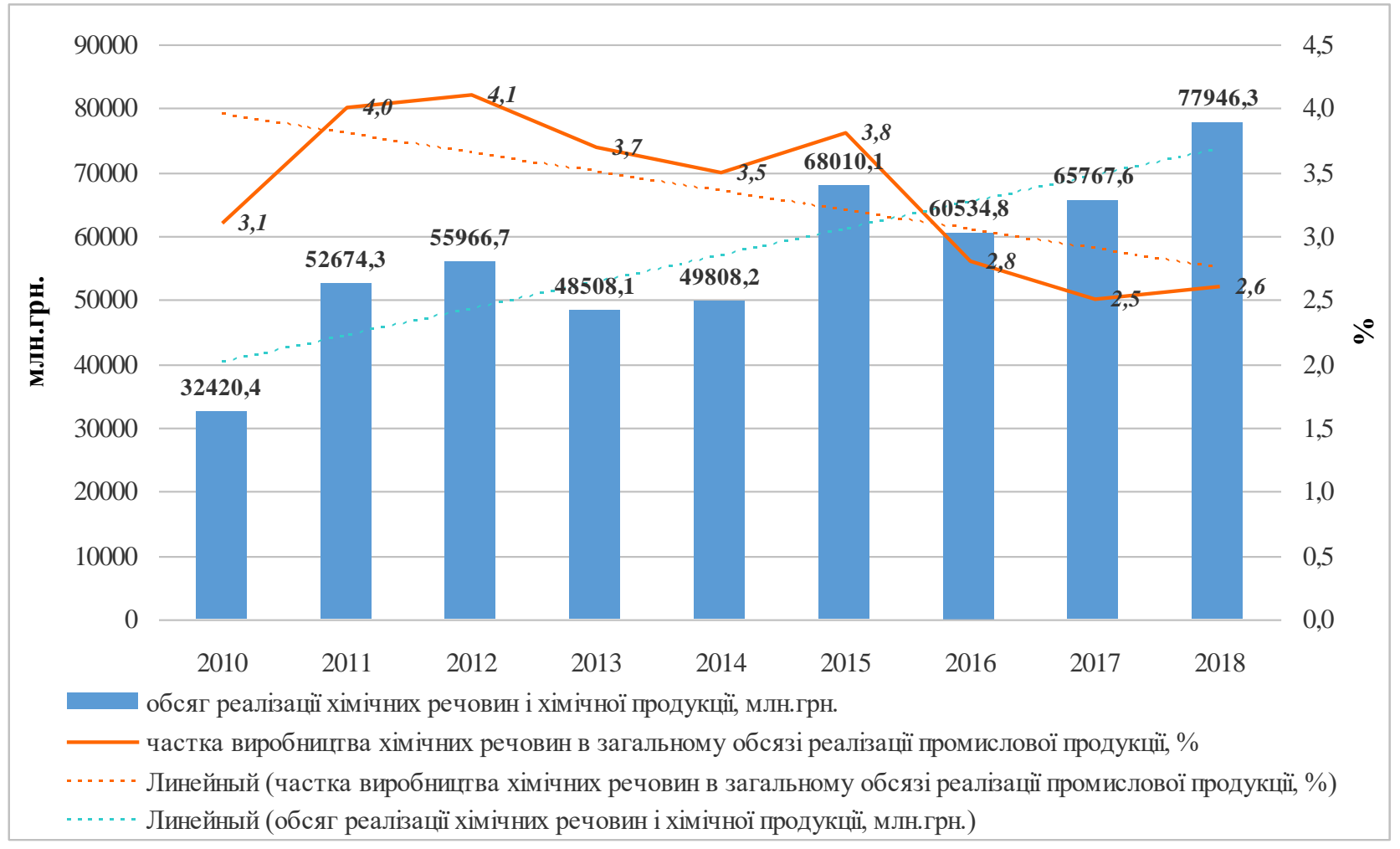

Рис. 1. Динаміка обсягу реалізації продукції хімічного виробництва та його частка в реалізації промислової продукиії в Україні

Джерело: побудовано за даними [4].

За період 2010-2018pp. реалізація хімічної продукції має тенденцію до зростання, але на цьому фоні обсяги реалізації зменшувались у 2013 та 2016 роках. На відміну від абсолютного виміру, частка хімічної продукції в загальному обсязі реалізації промислового виробництва має негативний тренд на тлі незначних піднесень (у 2011, 2012, 2015 та 2018 роках).

В Україні серед хімічних товарів за обсягами виробництва та реалізації лідирують: аміак безводний, сірчана кислота, сечовина, нітрат амонію, спирт етиловий та шампуні. Всього вітчизняними хімічними підприємствами випускається більше 50 тис. найменувань різних товарів, 
більша частина яких спрямовується в інші галузі промисловості (в першу чергу, в легку промисловість, сільське господарство та машинобудування), а менша - побутова хімія, косметичні та інші товари народного вжитку. Аутсайдерами за обсягами хімічної продукції вітчизняного виробництва є засоби для гігієни ротової порожнини та зубів, а також засоби для завивки, випрямлення та фіксації волосся.

В період 2010-2018pр. в хімічній галузі щорічно скорочувалась чисельність персоналу, що також відбилось на показнику частки зайнятих на хімічному виробництві серед зайнятих в промисловості (рис. 2).

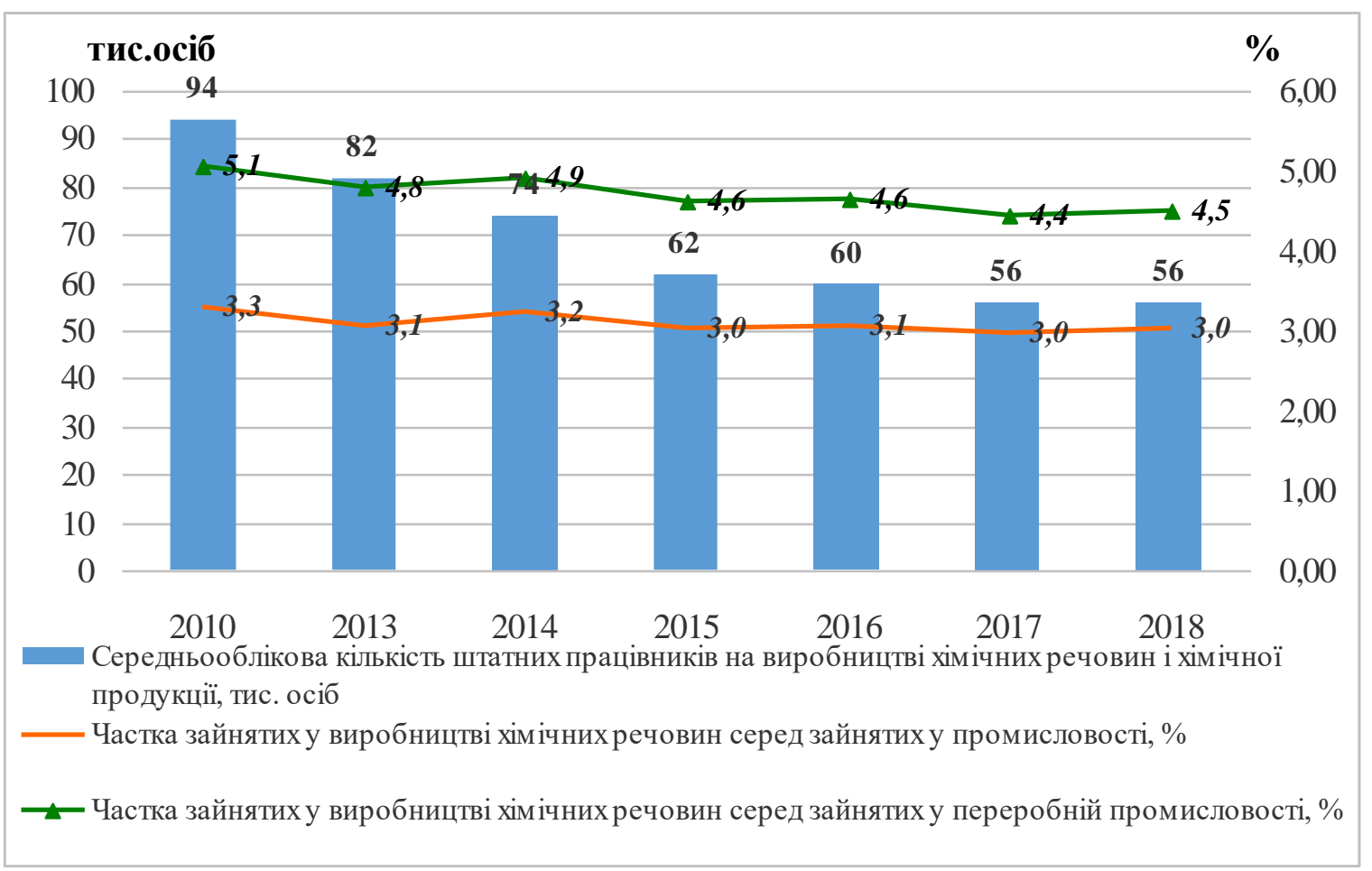

Рис. 2. Кількість та частка зайнятих у хімічному виробництві в Україні

Джерело: побудовано за даними [10].

В 2018p. в порівнянні з 2010p. середньооблікова чисельність штатних працівників скоротилась на 38 тис.осіб (або на 40, 4\%). Питома вага зайнятих у виробництві хімічних речовин хоча й зростала у 2014 та 2016 роках, але також має тенденцію до зменшення. Враховуючи важку ситуацію на ринку праці за умов економічної кризи, яка почалася в 2014p., скорочення персоналу хімічних підприємств призводило до зростання кількості безробітних, що в свою чергу, сприяло зростанню чисельності трудових мігрантів переважно до країн Східної та Західної Свропи, а також до РФ. Згідно результатів першого загальнонаціонального вибіркового обстеження домогосподарств 3 питань трудової міграції, проведеного ще в 2009 році, вже на той час Україна була однією 3 найбільших країн-донорів робочої сили в Свропі. [2]

В 2018p. в порівнянні з докризовим 2013р. у структурі виробництва окремих видів хімічних речовин та хімічної продукції відбулись певні зміни (рис. 3).

Суттєво зменшились обсяги виробництва основних хімічних речовин промислового призначення (аміаку, сечовини, спирту етилового, нітрату амонію та ін.), але значно зросли обсяги виробництва товарів народного споживання (косметичних товарів, засобів догляду за волоссям, шкірою, для гігієни ротової порожнини та ін.).

Значні падіння обсягів виробництва основних хімічних речовин пов'язано як із суттєвим зростанням цін на сировину, в першу чергу, природний газ, так i 3 руйнуванням хімічних підприємств та коопераційних зв'язків між підприємствами в ході бойових дій на Сході країни. Відомо, що складна виробнича структура $є$ особливістю хімічної промисловості, - технологічні процеси поєднують близько 200 виробництв, які поділяють на чотири великі групи: гірничо-хімічна 
промисловість, виробництво хімічних речовин і хімічної продукції, виробництво фармацевтичних продуктів і препаратів, виробництво гумових і пластмасових виробів.

Яскравим прикладом втраченого потенціалу є Лісічанський содовий завод - єдине підприємство в Україні, яке випускало харчову соду. 3 2014p. Україна не має власного содового виробництва i тепер лише фасує імпортовану з Туреччини соду.

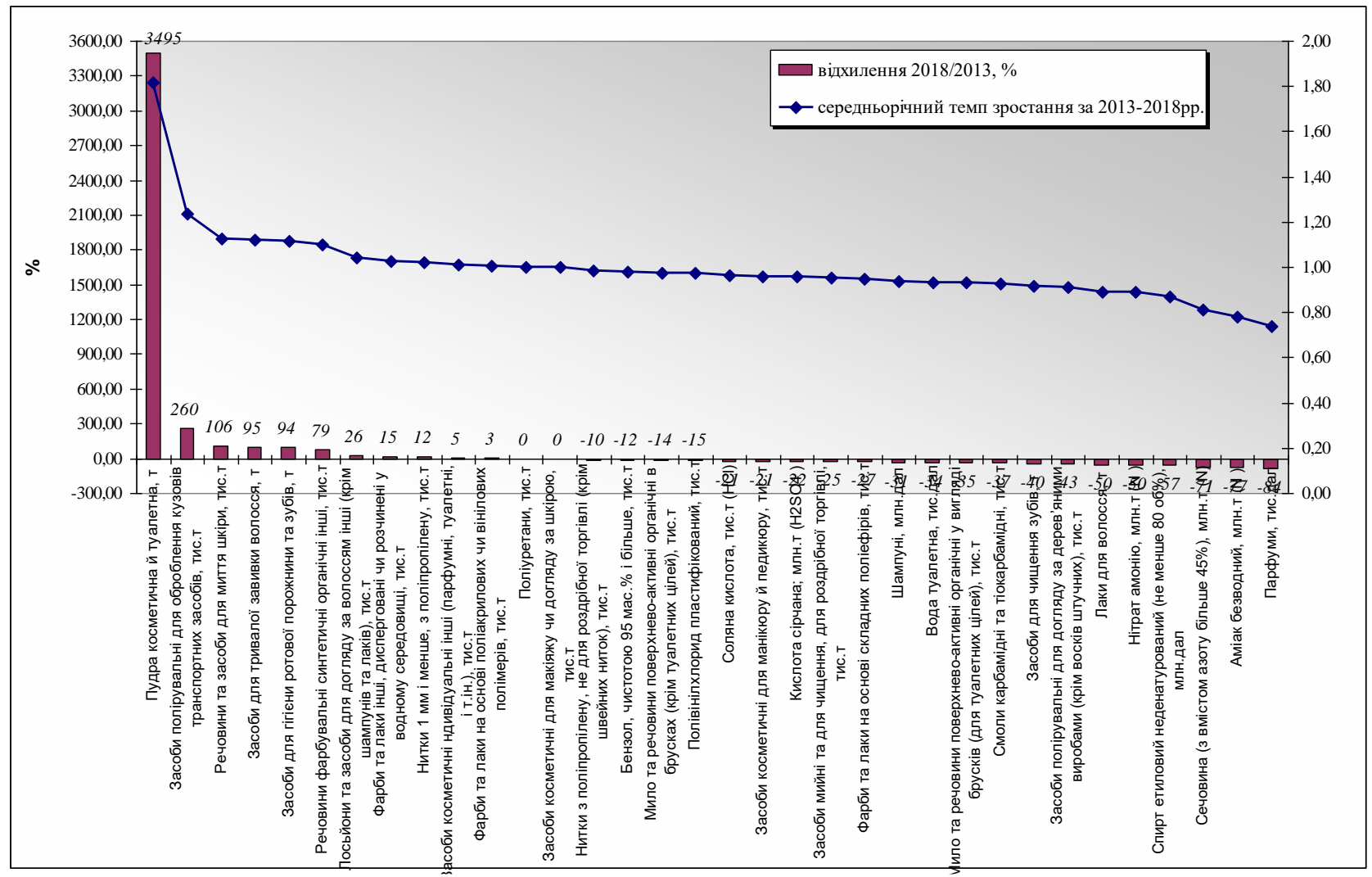

Рис. 3. Змінювання обсягів виробництва хімічних речовин та хімічної продукиії в Україні в 2013-2018pp.

Джерело: побудовано за даними [10].

Результатом негативних змін в галузі стало зростання імпорту хімічних речовин та хімічної продукції з КНР, що сприяє створенню робочих місць та зростанню доходів в китайській хімічний промисловості, але погіршує ситуацію в національній економіці України та на ринку праці зокрема.

Домінуючим чинником у виборі певної галузі для персоналу $\epsilon$ заробітна плата та іï співставлення з динамікою рівня цін (рис. 4-5).

Аналіз середньомісячної номінальної заробітної плати штатних працівників за видами економічної діяльності у промисловості показує, що за період 2010-2018pp. на хімічних підприємствах заробітна плата підвищувалась в середньому на 15,6\% за рік. Це 12 -та сходинка 3 16ти по основних галузях промисловості України. Таким чином, за критерієм доходів хімічне виробництво не входить до десятки галузей, які лідирують за цим показником, i, в сукупності 3 шкідливими та небезпечними умовами праці на хімічних підприємствах не є особливо привабливим для робочої сили. Антимотиватором для персоналу є затримка у виплаті заробітної плати: станом на 1 лютого 2019p. сума заборгованості з виплати заробітної плати у виробництві хімічних речовин і хімічної продукції становила 41,4 млн. грн. [5]. 


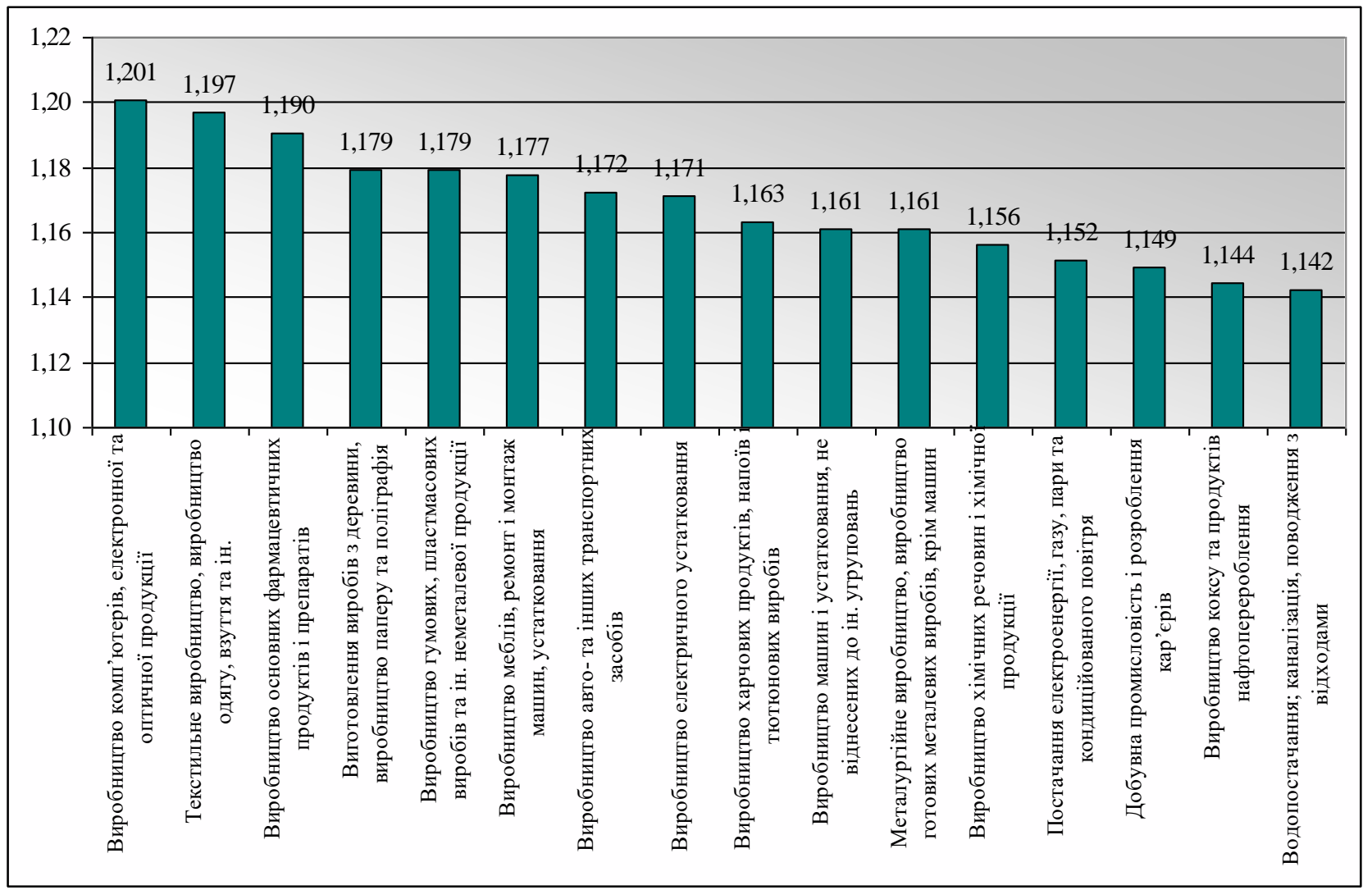

Рис. 4. Середньорічні темпи зростання заробітної плати в галузях промисловості України за 2010-2018pp.

Джерело: побудовано за даними [8], [10].

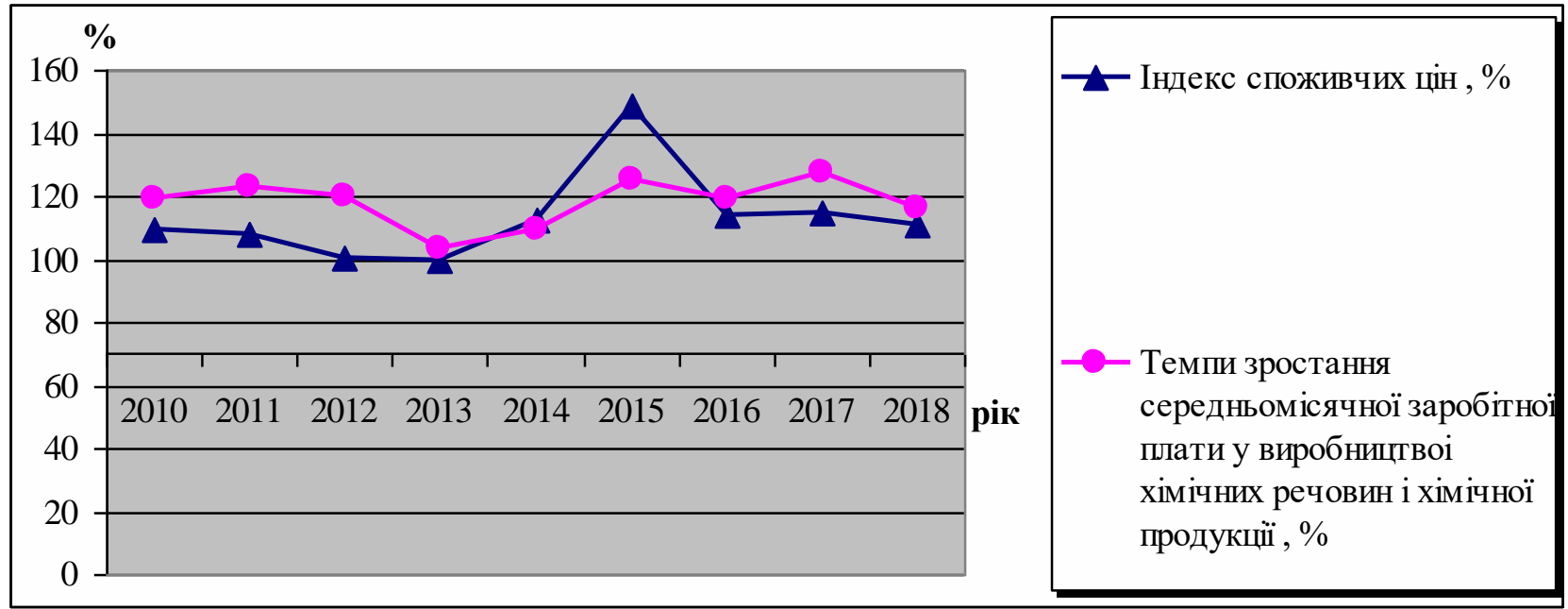

Рис. 5. Темпи зростання ЗП у хімічному виробнищтві та індекс споживчих цін в Украӥні за 2010-2018pp.

Джерело: побудовано за даними [8], [10].

Співставлення темпів зростання заробітків у хімічному виробництві 3 індексом споживчих цін показує перевищення темпів інфляції над темпами зростання заробітної плати в 2014-2015pр., на початку економічної кризи. Але вже у 2016р. темпи зростання заробітної плати перевищили темпи інфляції на споживчому ринку. Слід також враховувати, що багато років фахівці дорікають на недосконалу методику розрахунку рівня цін, яка показує занижені результати. Так, наприклад, 
зростання цін на комунальні витрати в 2014-2018pp., які займають велику частину витрат в бюджеті пересічних українців, на порядок перевищувало зростання заробітних плат. Ціна на основні продукти харчування також зросли значно більше, ніж це відображають узагальнені статистичні показники.

Враховуючи, що хімічне виробництво є одним з найбільших забруднювачів серед інших галузей матеріального виробництва, розглянемо показник витрат на охорону навколишнього природного середовища. В 2018р. витрати на екологію в переробної промисловості України склали 10323,8 млн.грн., 3 них в хімічному виробництві - 1139,4 млн.грн. , що становить 12\% загального обсягу витрат (рис. 6).

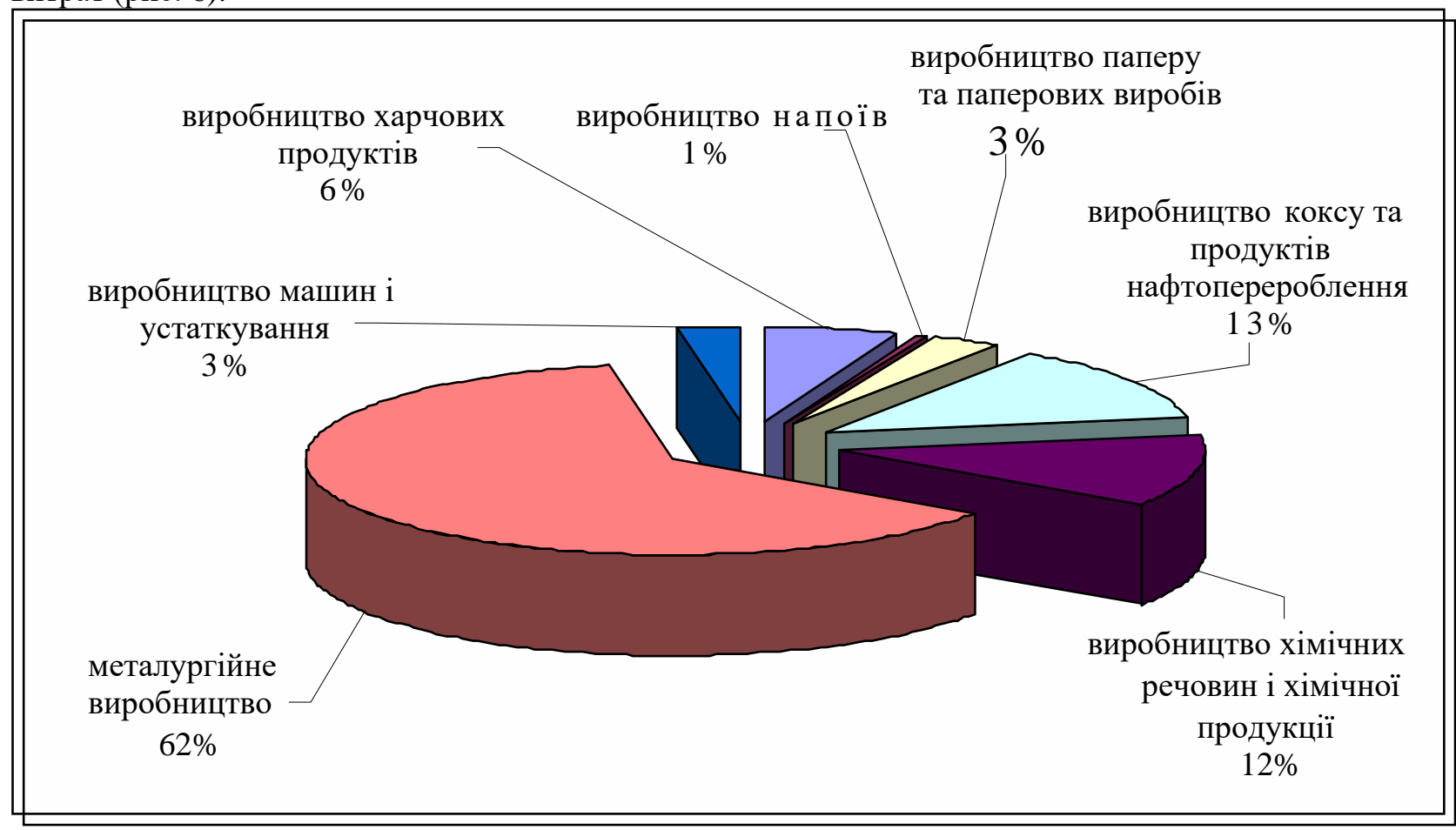

Рис. 6. Витрати на екологію за галузями переробної промисловості Украӥни в $2018 p$.

Джерело: побудовано за даними [10]

Викликає занепокоєння структура екологічних витрат в хімічній галузі: 3 загальної суми, що спрямовується на охорону навколишнього природного середовища 95,2\% складають поточні витрати, а капітальні інвестиції, спрямовані на оновлення матеріально-технічної бази та вдосконалення технологій становлять лише 4,8\%, 3 них витрати на капітальний ремонт - 0,93\%. 3 урахуванням того, що хімічне виробництво України базується переважно на застарілих (ще 3 радянських часів) технологіях, таке співвідношення є вкрай негативним. Тобто левова частка витрат іде на мінімізацію негативного впливу хімічного виробництва на навколишне середовище за незмінних брудних ресурсномістких технологіях і тільки 4,8\% коштів витрачається на капітальні інвестиції. А для того, щоб відбулась докорінна зміна екологічного стану галузі з урахуванням сучасних екологічних вимог, співвідношення капітальних та поточних витрат повинно бути 3 перевагою в бік капітальних інвестицій.

Енергоресурси та їх вартість - одна з найгостріших проблем вітчизняної економіки. В хімічному виробництві, яке використовує енергоресурси не тільки як джерело енергії, але й як сировину (в першу чергу, природний газ), значне їх подорожчання суттєво гальмує розвиток галузі, а брак власних коштів не дає можливості великим хімічним підприємствам оновити технології та обладнання.

Динаміка використання енергоресурсів в хімічному виробництві представлена на рис. 7.

В 2014-2017pp. спостерігаємо щорічне зменшення споживання електричної та теплової енергії на хімічному виробництві, але це відбувалось не за рахунок впровадження ресурсозберігаючих 
технологій, а через скорочення обсягів виробництва та реалізації як наслідку економічної кризи. В 2017-2018pp. суб'єкти господарювання в Україні поступово почали пристосовуватися діяти в умовах економічної кризи, хімічна галузь також повільно стала нарощувати обсяги виробництва i, відповідно, збільшувати кількість споживання енергоносіїв.

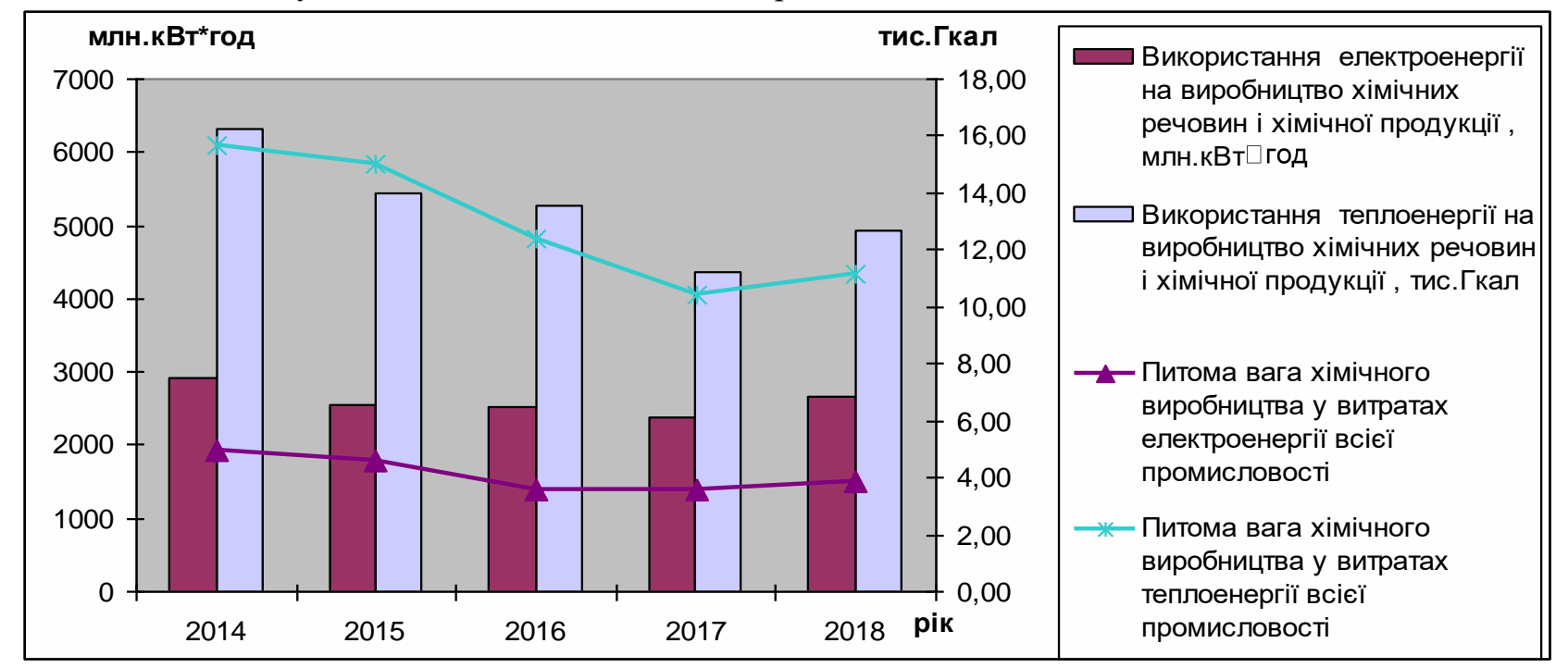

Рис. 7. Використання енергії в хімічному виробництві в Україні за 2014-2018рр.

Джерело: побудовано за даними [9],[10].

Значне подорожчання вартості енергоносіїв та сировини збільшило собівартість хімічного виробництва та вимусило виробників підняти ціни. Ціновий чинник також вплинув на зниження попиту на вітчизняну хімічну продукцію як на внутрішньому, так і на зовнішньому ринках. Від такої ситуації виграли китайські виробники хімічних речовин - їх продукція за ціновим чинником на сьогодні є більш конкурентоздатною.

Проаналізуємо змінювання індексів промислової продукції в хімічному виробництві та порівняємо їх з індексами в промисловості (рис. 8).

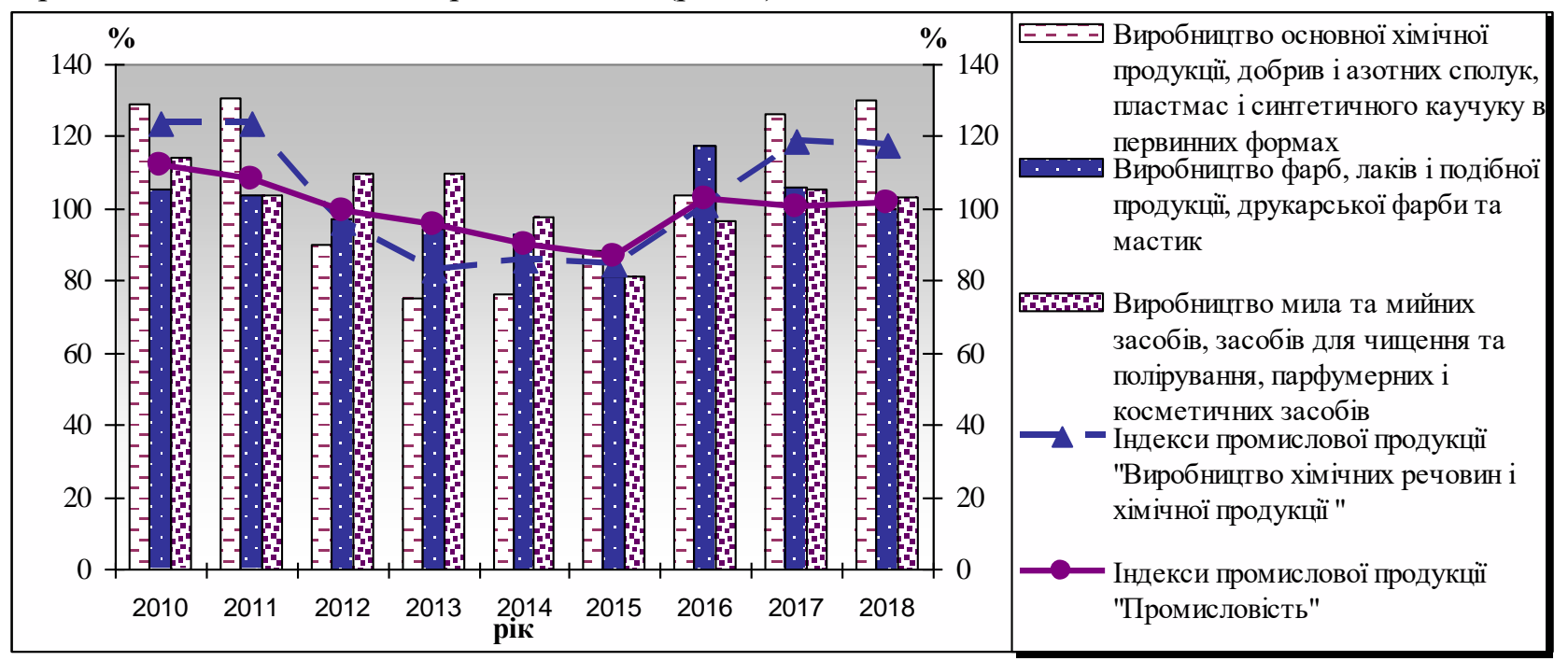

Рис. 8. Індекси промислової продукції всієї промисловості та в хімічному виробництві в Украӥні за 2010-2018pp. [8], [10]

Джерело: побудовано за даними [8],[10].

Протягом 2010-2018pp. мінімальний індекс промислової продукції в хімічній галузі спостерігаємо в 2013p. (83,1\%). Мінімальний індекс в промисловості $(87 \%)$ зафіксований в 2015p., - 
це свідчить про більшу інертність всієї промисловості в порівнянні з хімічною індустрією. Зниження індексів виробництва хімічних речовин та хімічної продукції в 2012-2013pр. пояснюється зростанням цін на сировину, комунальних тарифів, високою ресурсомісткістю, застарілими технологіями та невідповідністю вітчизняної продукції сучасним вимогам світового ринку. В 2014p. зростання обсягів виробництва відбулось через стрімке падіння гривні по відношенню до іноземних валют, внаслідок чого товари-конкуренти іноземного виробництва стали значно дорожчими i покупці на внутрішньому ринку змістили попит на продукцію вітчизняного виробництва. В 2015p. дестабілізація фінансово-економічної ситуації в країні посилилась і в багатьох галузях сфери матеріального виробництва знизився попит на продукцію, а підприємства вимушені були скорочувати обсяги виробництва.

В 2016-2017pp. суб'єкти господарювання в хімічній промисловості вже почали пристосовуватись до діяльності в умовах кризи. За досліджуваний період (2010-2018pp.) коефіцієнт варіації індексу промислової продукції хімічної галузі вдвічі перевищив варіацію виробництва всієї промисловості (16,6\% проти 8\%), але хімічне виробництво в 2017-2018pр. показало значно кращі результати $(18,4 \%$ та $17,4 \%$ проти $0,4 \%$ та $1,6 \%)$ [10]. Хоча більше значення коефіцієнту варіації та більша амплітуда коливань в хімічній промисловості свідчать про більшу ризикованість галузі, але в кризових умовах 2016 року галузь вже змогла переломити ситуацію і вже в 2017 та 2018 роках показати значно кращі результати, ніж вся вітчизняна промисловість.

3 початку військових дій на Сході країни відбулось переформатування сталої регіональної структури вітчизняної хімічної промисловості, внаслідок чого виник дисбаланс у розвитку хімічних виробництв [1].

Рейтинг регіонів України за індексом промислової продукції в хімічному виробництві в 2018p. представлений на рис. 9.

На світовому ринку сучасна хімічна галузь демонструє активну динаміку та відрізняється високою наукомісткістю. Для того, щоб забезпечити підгрунтя для свого розвитку та підвищити ефективність своєї діяльності, вітчизняні хімічні підприємства повинні приділяти першочергову увагу технічному переозброєнню виробництва та підготовці випуску інноваційної, конкурентоспроможної продукції. Підгрунтям для корінних змін в галузях вітчизняної промисловості є обсяг капітальних інвестицій.

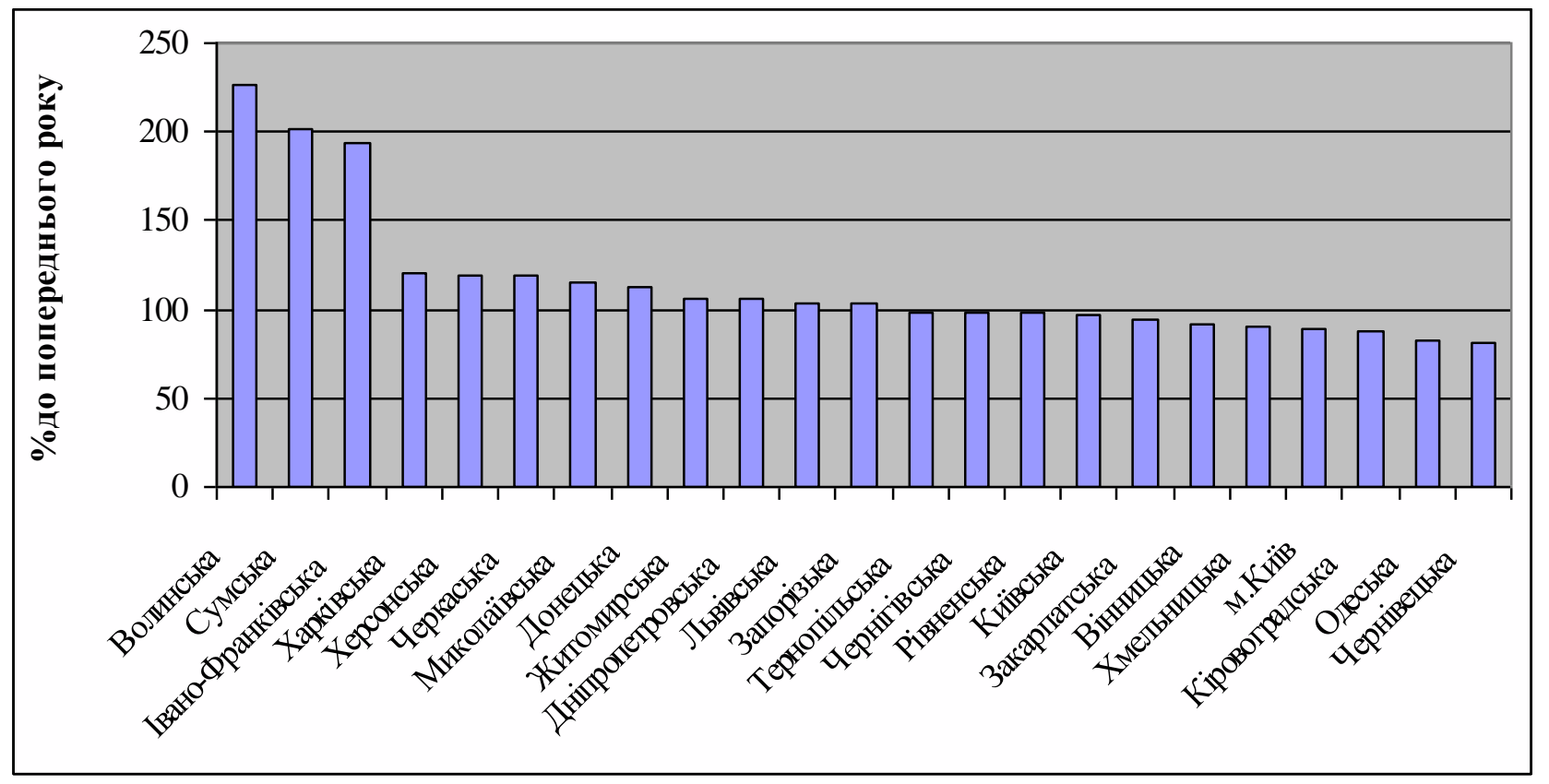

Рис. 9. Індекси промислової продукцї̈ у виробництвво хімічних речовин і хімічної продукції за регіонами Украӥни в 2018p.

Джерело: побудовано за даними [6]. 
За 2010-2018pр. виробництво хімічних речовин та хімічної продукції посідає 6 сходинку за сумарною величиною капітальних вкладень серед інших галузей переробної промисловості України (рис. 10).

Локальні максимуми капітальних вливань в хімічну індустрію спостерігалися в 2013 та 2017 роках. За досліджуваний період найменше значення величини капітальних інвестицій в галузі було в 2015р. (рис. 11)

Кореляційний та регресійний аналіз динаміки капітальних вкладень в галузь та динаміки обсягів реалізації дасть можливість визначити як капітальні інвестиції впливають на результати діяльності галузі. Для того, щоб визначити міцність та напрямок зв'язку між капітальними інвестиціями та обсягом реалізації хімічної продукції, розрахуємо коефіцієнт кореляції (табл. 1).

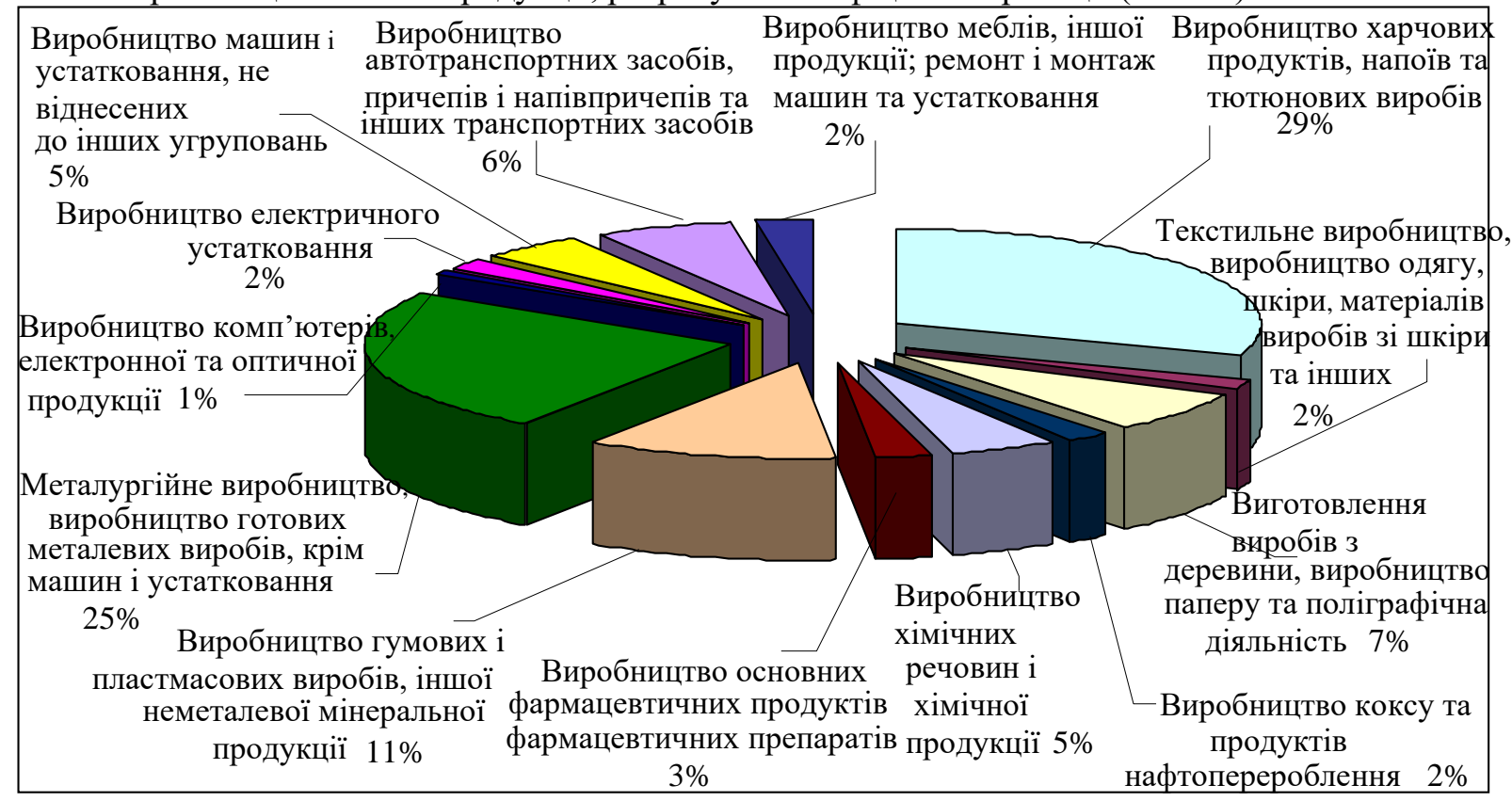

Рис. 10. Капітальні інвестиції в галузях переробної промисловості Україні за 2010-2018рр. Джерело: побудовано за даними [8],[10]

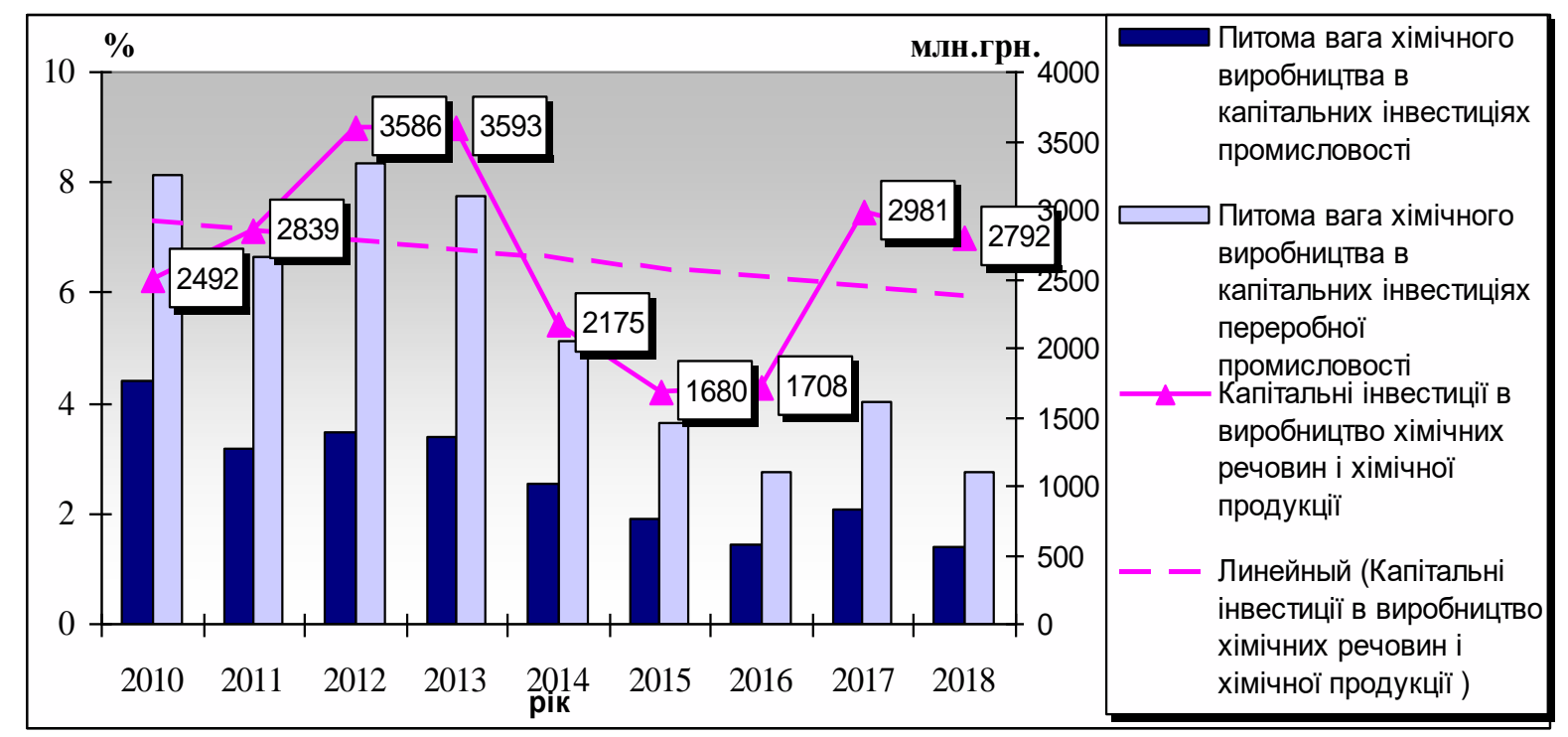

Рис. 11. Капітальні інвестиції в хімічній галузі та їх частка в сукупних інвестищіях в промисловості Україні за 2010-2018рр.

Джерело: побудовано за даними [8],[10] 
Отримані від’ємні значення коефіцієнту кореляції показують, що між змінними (капітальними інвестиціями та обсягом реалізаціі) є слабкий негативний зв'язок. Автор свідомо не вказує, яка із змінних $є$ незалежною, а яка залежною, оскільки обидва цих параметри пов'язані між собою обопільними зв'язками: логічно, що капітальні інвестиції покликані усучаснити матеріальнотехнічну базу підприємств, внаслідок чого ті зможуть виробляти і пропонувати на ринок більш якісну та різноманітну продукцію, що впливатиме на обсяг продажів; а виручка від реалізації за мінусом всіх відрахувань та сплати податків створюватиме прибуток, частина якого може бути спрямована на капітальні інвестиції в наступних періодах.

Таблиия 1

Вимірювання залежності між капітальними інвестиціями та обсягом реалізації в хімічній галузі [8], [10]

\begin{tabular}{|c|c|c|c|c|c|c|c|c|c|c|c|c|c|}
\hline & \multicolumn{9}{|c|}{ Рік } & \multicolumn{4}{|c|}{$\begin{array}{l}\text { Коефіцієнти кореляції } 3 \\
\text { урахуванням часового лагу }\end{array}$} \\
\hline & 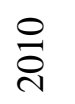 & $\overrightarrow{\bar{i}}$ & $\frac{\sim}{\stackrel{N}{d}}$ & $\frac{m}{\stackrel{n}{i}}$ & $\underset{\sim}{\stackrel{\Delta}{*}}$ & $\frac{n}{i}$ & $\frac{0}{\stackrel{i}{d}}$ & 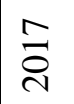 & $\frac{\infty}{\stackrel{\infty}{i}}$ & $\tau=0$ & $\tau=1$ & $\tau=2$ & $\tau=3$ \\
\hline $\begin{array}{l}\text { Капітальні інвести-ції } \\
\text { в виробництво } \\
\text { хімічних речовин і } \\
\text { хімічної продукції }\end{array}$ & $\underset{\sim}{\stackrel{\alpha}{d}}$ & $\underset{\text { ळે }}{\stackrel{N}{N}}$ & $\begin{array}{l}\infty \\
\infty \\
n \\
m\end{array}$ & $\begin{array}{l}\text { مे } \\
\stackrel{n}{n}\end{array}$ & $\frac{n}{\frac{n}{2}}$ & $\begin{array}{l}\stackrel{\infty}{0} \\
\underline{-}\end{array}$ & $\stackrel{\infty}{\stackrel{2}{2}}$ & $\begin{array}{l}\bar{\infty} \\
\stackrel{\curvearrowright}{\sim}\end{array}$ & 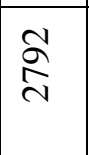 & & & & \\
\hline $\begin{array}{l}\text { Обсяг реалізації у } \\
\text { виробництві хімічних } \\
\text { речовин і хімічної } \\
\text { продукції }\end{array}$ & 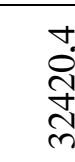 & 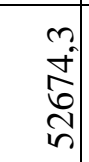 & $\begin{array}{l}1 \\
8 \\
2 \\
2\end{array}$ & $\begin{array}{l}- \\
\infty \\
0 \\
0 \\
\infty \\
0\end{array}$ & $\begin{array}{l}r \\
\infty \\
\infty \\
\infty \\
o\end{array}$ & $\begin{array}{l}-7 \\
0 \\
0 \\
0 \\
0\end{array}$ & $\begin{array}{l}\infty \\
\substack{+n} \\
0\end{array}$ & $\begin{array}{l}6 \\
6 \\
6 \\
6\end{array}$ & $\begin{array}{l}n \\
0 \\
2 \\
2 \\
1\end{array}$ & $-0,14$ & $-0,44$ & $-0,51$ & $-0,30$ \\
\hline
\end{tabular}

Від’ємне значення коефіцієнту кореляції означає, що у міру зростання капітальних інвестицій буде скорочуватись приріст обсягів реалізації, а у випадку зменшення капітальних інвестицій обсяги реалізації будуть збільшуватись. Надто слабка залежність між інвестиціями та обсягом реалізації може пояснюватися тим, що ефект від капітальних вкладень проявлятиметься не одночасно із вкладеннями, а із запізненням, тобто з певним часовим лагом. Розраховані значення коефіцієнтів кореляції між значеннями в ряду інвестицій та обсягами реалізації наступного року $(\tau=1)$ показує втричі більш сильну обернену залежність між двома показниками. При зміщенні обсягів реалізації на 2 роки ( $\tau=2)$ від'ємна кореляція ще посилюється, а от при зміщенні на 3 роки $(\tau=3)$ взаємозв'язок слабшає.

Неодмінно слід звернути увагу на те, що навіть із врахуванням часового лагу величина коефіцієнтів кореляції змінюється чисельно, але від'ємний напрямок взаємозв'язку залишається. Це свідчить або про неефективність використання інвестованих коштів, або про те, що на обсяг реалізації впливають негативні фактори більшої сили, які зводять нанівець позитивний вплив капітальних вкладень.

Для двох параметрів, що аналізуються, побудуємо лінію регресії (рис. 12а) та б)).

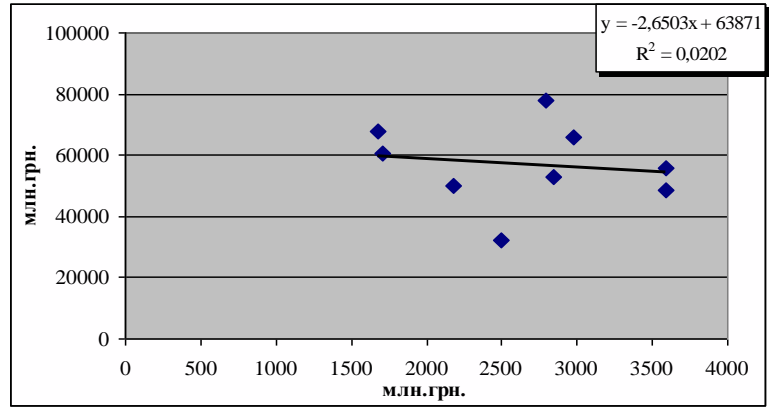

a) часовий лаг $=0$

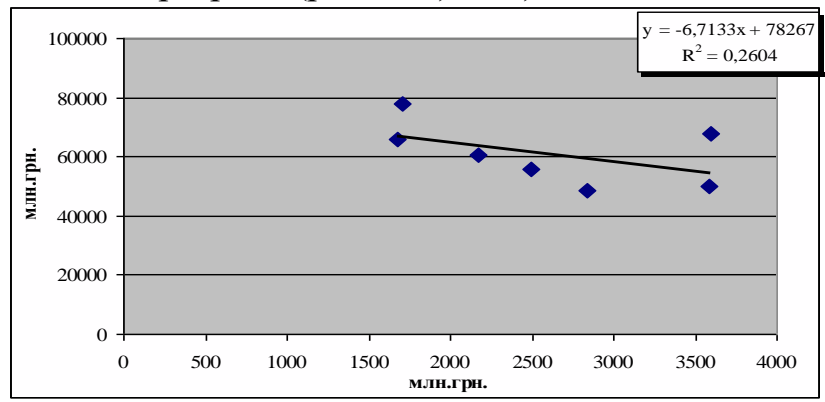

б) часовий лаг $=2$

Рис. 12. Лінія регресії для визначення впливу зміни капітальних інвестииій на обсяги реалізаиії хімічної продукиії в Україні

Джерело: розраховано та побудовано автором за даними [8],[10] 
Хаотичний розкид значень двох параметрів в одному році свідчить про те, що капітальні інвестиції не дають швидкого ефекту “рік-в-рік”. Із зміщенням обсягів реалізації, як залежного параметру, на один, два та три роки в усіх випадках отримуємо від’ємну лінійну швидкість лінії регресії, що підтверджує обернений взаємозв'язок між інвестиціями та реалізацією продукції. Величина достовірності апроксимації лінії регресії $\epsilon$ найбільшою з дворічним часовим лагом, але все одно розсіювання значень параметрів свідчить про несистемність капітальних вкладень та надто низьку їх віддачу.

У 2018 році інноваційною діяльністю в хімічній галузі займалися 40 підприємств (що на 2 менше, ніж у 2017p. та на 4 менше, ніж у 2015р.), або 24,8\% усіх підприємств (рис. 13).

В 2018 p. за відносним значенням це - 6 -е місце після фармацевтичного виробництва $(58,3 \%)$, виробництва комп'ютерів (34\%), виробництва автотранспортних засобів $(30,2 \%)$, виробництва електричного устаткування $(25,2 \%)$ та виробництва інших машин $(22,6 \%)$.

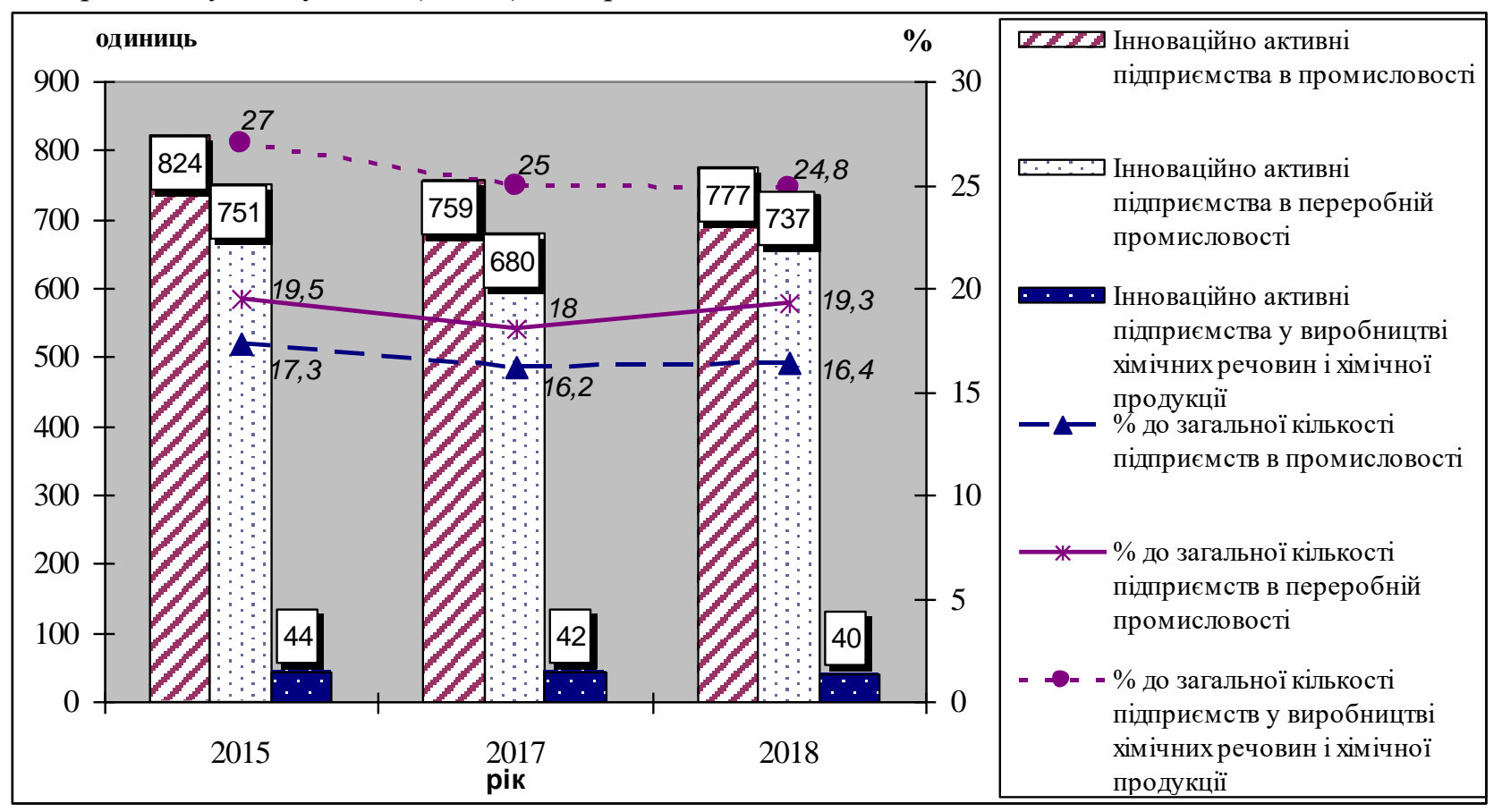

Рис. 13. Кількість інноваційно активних підприємств в промисловості та хімічному виробництві в Украӥні

Джерело: побудовано автором за даними [9],[10]

Абсолютний та відносний показники інноваційно активних підприємств в хімічній промисловості мають тенденцію до зменшення, що є негативним чинником для розвитку, оскільки існуючий стан справ в традиційних галузях матеріального виробництва в Україні можливо суттєво змінити на краще тільки за рахунок системного та планомірного впровадження інновацій та виробництва інноваційних видів продукції.

Динаміка обсягу реалізації інноваційної продукції в хімічній галузі та його частки в загальному обсязі реалізації представлена на рис. 14.

Стрімке падіння обсягів реалізації інноваційної продукції у хімічному виробництві пояснюється невиправдано високим ризиком інноваційної діяльності для суб'єктів господарювання в кризових умовах держави, на території якої з весни 2014p. ведуться бойові дії.

Зменшення інноваційної активності проілюстровано також і скороченням випуску інноваційної продукції за двома основними типами новизни (рис. 15). 


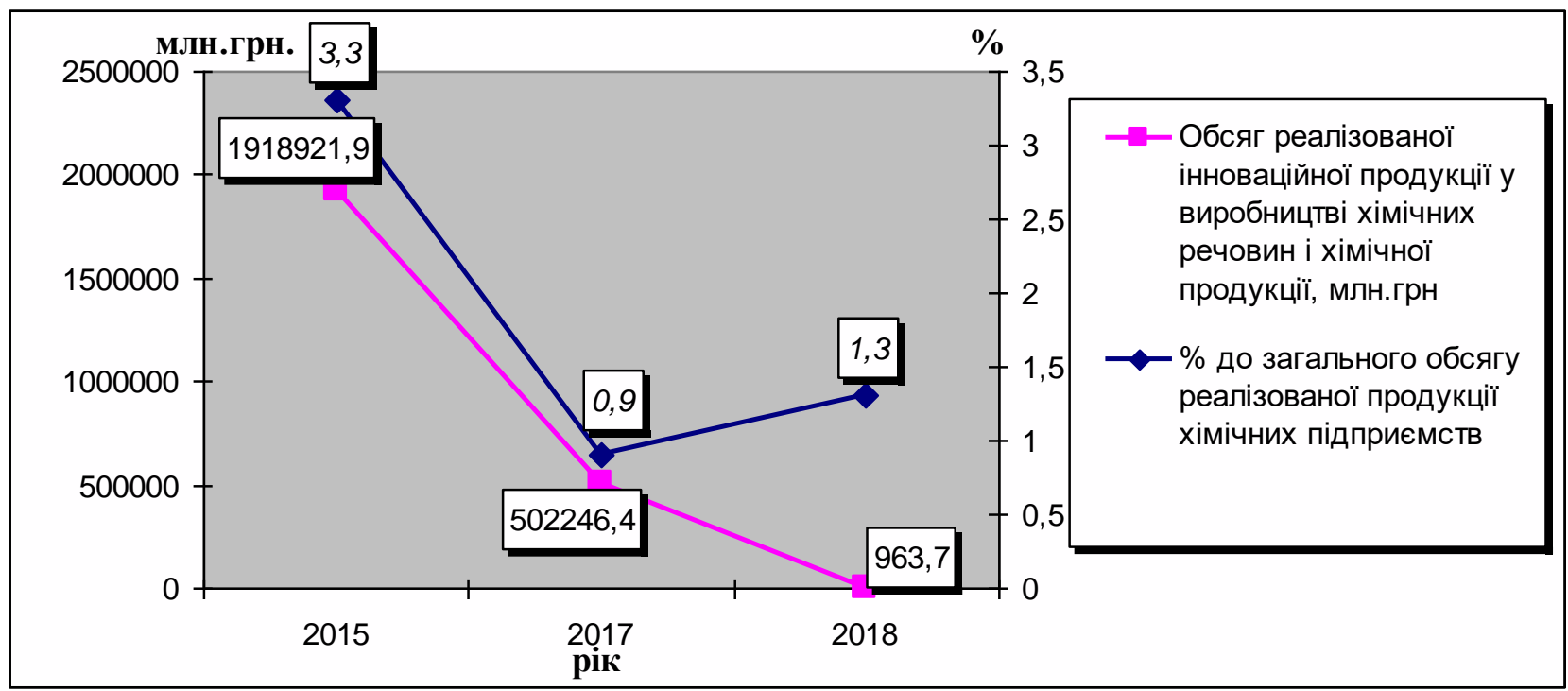

Рис. 14. Реалізація інноваційної продукиії у виробництві хімічних речовин і хімічної продукції в Україні

Джерело: розраховано та побудовано автором за даними [3]

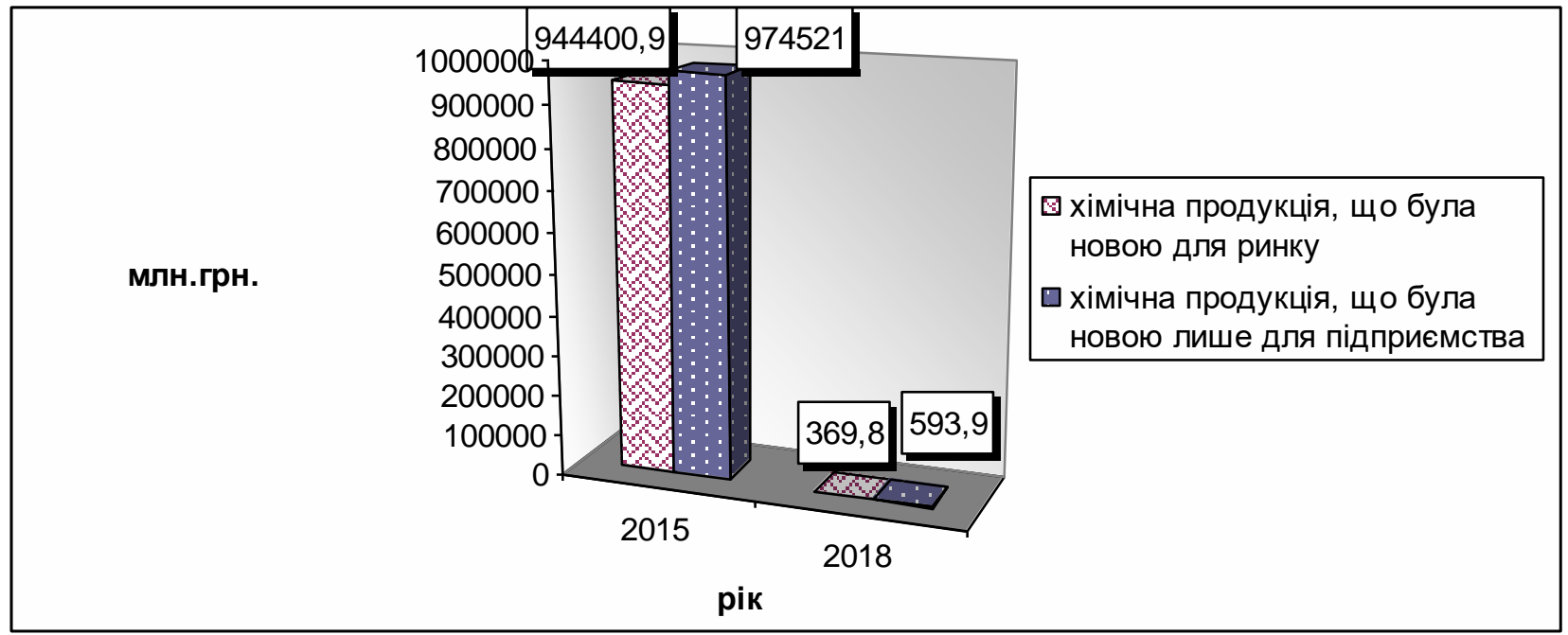

Рис. 15. Типи новизни інновачійної продукції в хімічній промисловості України

Джерело: побудовано автором за даними [3].

Інноваційну активність вітчизняних підприємств стримує брак вільних власних коштів (адже для недержавних підприємств це основне джерело фінансування інноваційних витрат), а дорожнеча кредитних ресурсів та непередбачуваність розвитку національної економіки не дають можливості підприємствам користуватися позиковими коштами.

Враховуючи зміну статистичної методики, яка робить некоректним порівняння даних до 2014 року включно, аналіз показників інноваційної діяльності в хімічній промисловості за 2015-2018pp. свідчить про суттєве скорочення інноваційної активності в галузі, що відбулось під впливом економічної кризи в Україні та втрати територіальної цілісності країни. В умовах кризи ризик виробництва та реалізації інноваційної продукції значно зростає, тому зрозуміло, що виробники зменшили обсяги виробництва та реалізації інновацій.

В час науково-технічного прогресу скорочення інноваційної активності в будь-якій галузі $€$ перешкодою для іiі розвитку, оскільки саме інноваційна діяльність здатна забезпечити прорив, стрибок з рівня сучасного стану до більш високої сходинки розвитку. На тлі негативних змін 
зростання відсотку інноваційної продукції в обсязі реалізації продукції хімічних підприємств в 2018p. в порівнянні з 2017p. залишає надію на покращення стану галузі. А для того, щоб розвиток промислового виробництва в країні відбувався системно та планомірно, потрібна політична воля вищих держслужбовців країни, виважена державна галузева політика та обгрунтоване використання важелів державного регулювання.

Висновки і пропозиції. 3 2014p. п'ять років, що минули, були найважчими 3 початку 2000-х для всієї промисловості України і для хімічної індустрії зокрема. Економічна криза, що почалась в країні, обумовила тенденцію до погіршення основних показників діяльності суб'єктів господарювання, що суттєво відкинуло національних виробників у розвитку назад.

Головна проблема, що сьогодні гальмує розвиток промисловості України, - нестабільна загальна економічна та політична ситуація в країні, за якої господарська діяльність в будь-якій галузі національної економіки є високо-ризикованою та важко передбачуваною. Озброєний конфлікт на Сході країни спричинив руйнування частини підприємств та коопераційних зв'язків між підприємствами; втрата Криму також негативно позначилась на діяльності вітчизняної промисловості, в т.ч. і хімічної галузі, що відбилось на ресурсному потенціалі хімічних виробництв в регіональному розрізі та створило регіональні диспропорції у розвитку хімічної промисловості.

Низький рівень платоспроможного попиту на внутрішньому ринку та жорстка конкуренція на світових ринках; трудова міграція, відтік висококваліфікованих кадрів через щорічне скорочення обсягів виробництва, низький рівень заробітної плати та наявності значної суми заборгованості по заробітній платі в галузі; висока ресурсо- та енергомісткість хімічного виробництва, (особливо багатотоннажного); стрімке падіння темпів розробки, освоєння і випуску нової продукції; брак власних коштів підприємств як основного джерела інвестиційних ресурсів для фінансування інноваційного розвитку; різні стандарти та екологічні характеристики вітчизняного та європейського ринків, - всі ці чинники створюють перешкоди для вітчизняних виробників хімічних речовин і хімічної продукції.

Перспективи розвитку хімічної галузі пов'язані 3: впровадженням ресурсозберігаючих та безвідходних технологій; поліпшенням структури ресурсного потенціалу хімічних підприємств; підвищенням якості продукції, що випускається, i доведенням іiі до світових стандартів; підвищенням інноваційної активності та інвестиційної привабливості; політичною волею та державним стимулювання процесу технічного та технологічного оновлення виробничих фондів та інноваційної активності; сприянням держави (на рівні міжурядових контактів) у виході на нові ринки збуту; підйомом рівня автоматизації всіх стадій виробничого процесу та приведенням охорони праці й техніки безпеки для роботи персоналу у відповідність часу; реконструкцією ряду хімічних підприємств.

\section{Джерела та література}

1. Іщук С. О., Л. Созанський Л. Й., Коваль Л. П, Ляховська О. Виклики та перспективи розвитку хімічних виробництв у регіонах України: наукове видання НАН України. ДУ «Інститут регіональних досліджень імені М. І. Долішнього Наиіональної академії наук Украӥни»; Львів, 2018. -91 с.

2. Зовнішня трудова міграція населення України. Звіт проекту «Обстеження трудової міграції в Україні». - Український центр соціальних реформ, Київ, 2009.

3. Наукова та інноваційна діяльність України за 2015 рік. Статистичний збірник. //Державна служба статистики України. URL: http://www.ukrstat.gov.ua/.(дата звернення: 12.02.2020).

4. Обсяг реалізованої промислової продукції (товарів, послуг) за видами економічної діяльності у 20102018 роках). Державна служба статистики України. URL::http://www.ukrstat.gov.ua /(дата звернення: 11.02.2020.

5. Соціально-економічний розвиток України за січень 2019 року. URL: http://www.ukrstat.gov.ua/ (дата звернення: 11.02 .2020 .

6. Статистичний збірник "Регіони України" за 2019 рік. Частина II. URL:: http://www.ukrstat.gov.ua/.(дата звернення: 09.02.2020.

7. Статистичний щорічник України за 2010 рік. URL:http://www.ukrstat.gov.ua/.(дата звернення: 11.02.2020.

8. Статистичний щорічник України за 2014 рік. URL:: http://www.ukrstat.gov.ual.(дата звернення: 11.02.2020. 
9. Статистичний щорічник України за 2016 рік. URL:: http://www.ukrstat.gov.ua/.(дата звернення: 11.02.2020.

10. Статистичний щорічник України за 2018 рік. URL:y: http://www.ukrstat.gov.ua/.(дата звернення: 11.02.2020.

\section{References}

1. Ishchuk S.O., Sozanskyi L.Y., Koval L.P., Liakhovska O.V. (2018). Vyklyky ta perspektyvy rozvytku khimichnykh vyrobnytstv u rehionakh Ukrainy: naukove vydannia [Challenges and prospects for the development of chemical production in the regions of Ukraine: scientific publication]. Lviv, Institute of Regional Research named after M.I. Dolishniy of the NAS of Ukraine [in Ukrainian].

2. Zovnishnia trudova mihratsiia naselennia Ukrainy (2009) Zvit proektu «Obstezhennia trudovoi mihratsii v Ukraini». - Ukrainskyi tsentr sotsialnykh reform, Kyiv, [in Ukrainian].

3. Naukova ta innovatsiina diialnist Ukrainy za 2015 rik. Statystychnyi zbirnyk. Derzhavna sluzhba statystyky Ukrainy. URL: http://www.ukrstat.gov.ua/.( accessed: 12. February.2020). [in Ukrainian].

4. Derzhavna sluzhba statystyky Ukrainy. Obsiah realizovanoi promyslovoi produktsii (tovariv, posluh) za vydamy ekonomichnoi diialnosti u 2010-2018 rokakh). URL::http://www.ukrstat.gov.ua/ (accessed: 11 February 2020).

5. Sotsialno-ekonomichnyi rozvytok Ukrainy za sichen 2019 roku. URL: http://www.ukrstat.gov.ua/ (accessed: 11 February.2020.) [in Ukrainian].

6. Statystychnyi zbirnyk "Rehiony Ukrainy" za 2019 rik. Chastyna II. URL:: http://www.ukrstat.gov.ua/.(accessed: 09 February 2020). [in Ukrainian].

7. Statystychnyi shchorichnyk Ukrainy (2010). URL: http://www.ukrstat.gov.ua/. (accessed: 11 February 2020). [in Ukrainian].

8. Statystychnyi shchorichnyk Ukrainy (2014). URL: http://www.ukrstat.gov.ua/. (accessed: 11 February 2020). [in Ukrainian].

9. Statystychnyi shchorichnyk Ukrainy (2016). URL: http://www.ukrstat.gov.ua/. (accessed: 11 February 2020). [in Ukrainian].

10. Statystychnyi shchorichnyk Ukrainy (2018). URL: http://www.ukrstat.gov.ua/. (accessed: 11 February 2020). [in Ukrainian].

Стаття надійшла до редакції 20.02.2020 p. 